mutta samalla panelistit näkivät tarpeen edistää nimenomaan slavistiikan piiriin kuuluvien väitöskirjantekijöiden yhteistyötä. Ideaa lähdettiinkin kehittämään jatko-opiskelijoiden epämuodollisessa illanvietossa, jossa lähestulkoon kaikki konferenssiin osallistuneet jatko-opiskelijat olivat paikalla. Kaikissa Pohjoismaissa tilanne on se, että alan oppiaineet ovat melko pieniä omissa yliopistoissaan, ja valmius etsiä yhteistyökumppaneita maan rajojen ulkopuolelta on suuri, minkä osoitti myös kongressin hyvä osanottajamäärä.

Konferenssin puitteet Itä-Suomen yliopistossa olivat erinomaiset, ja Joensuun maantieteelli- nen läheisyys Venäjään ja sitä kautta slaavilaisen kielen ja kulttuurin näkyvyys kaupungin arjessa toi oman lisänsä aihetta käsittelevään tapahtumaan. Ohjelma oli rakennettu väljäksi niin, että kahvitauoille ja epämuodollisille keskusteluille jäi hyvin tilaa. Toki se tarkoitti myös sitä, että moni osallistuja ei ehtinyt olla paikalla konferenssin alusta aivan sen loppuun. Seuraava, vuonna 2022 järjestettävä Pohjoismainen slavistikongressi pidetään Oslossa.

Susan Ikonen, Eeva Kuikka, Jari Parkkinen \& Mika Perkiömäki

\title{
Tuotettuja mielikuvia ja Idäntutkimusta VIETSin kevätseminaarissa 2019
}

Venäjästä ja Euroopasta tuotettavia mielikuvia ja todellisuutta tarkasteltiin Venäjän ja Itä-Euroopan tutkimuksen seuran VIETSin vuotuisessa kevätseminaarissa Tieteiden talolla Helsingissä 10. toukokuuta. Seminaarin pääpuhujat olivat kulttuurin ja yhteiskunnan tutkijat Olga Davydova-Minguet (Karjalan tutkimuslaitos, Itä-Suomen yliopisto), Sigrid Kaasik-Krogerus (Musiikin, taiteen ja kulttuurin tutkimuksen laitos, Jyväskylän yliopisto) ja Kaarina Aitamurto (Aleksanteri-instituutti, Helsingin yliopisto).

Olga Davydova-Minguet pohti esityksessään "Voiko maahanmuuttaa historiaan, ja mihin historiaan? Karjalan keskitysleirien transnationaali muisti" maahanmuuton ja kansallisen muistin ja historian välistä suhdetta. Voivatko Suomen venäjänkieliset muuttaa Suomen historiaan? Pitääkö maahanmuuttajien omaksua maahanmuuttomaan käsitys historiasta, ja miten se tapahtuu? Taustana on yhtäältä monisuuntainen ja transnationaali muisti ymmärryksen ja solidaarisuuden tuottajana eri ryhmien välille ja toisaalta suvereeni muisti keskiössään kansakunta.

Tulkinnat Suomen ja Venäjän yhteisestä sotahistoriasta ovat erilaisia rajan eri puolilla. $\mathrm{Ne}$ nousevat esiin muistoa näkyväksi tekevässä työssä ja Suomen venäjänkielisten maahanmuuttajien keskusteluissa. Sodan ja Karjalan keskitysleirien muisto ja historia kyseenalaistavat maahanmuuton historiaan: minkä maan historiaan Suomen venäjänkieliset muutta(isi)vat?

Sodan jälkeisessä Neuvostoliitossa sotamuistoa häivytettiin, ja Suomi oli hyvän naapuruuden mallimaa. Myös kuvat saksalaisista ja suomalaisista miehittäjistä hämärtyivät fasisteiksi. Nyky-Venäjällä sodan muisto on tärkeä poliittinen resurssi. Se myös leviää yli rajojen, kuten Helsinginkin kuolemattoman rykmentin marsseissa, joissa venäläiset kunnioittavat sodassa kuolleiden omaisten muistoa kävelemällä kulkueena heidän valokuviensa kanssa. Karjalan keskitysleirit ovat puolestaan Suomen venäjänkielisten verkkokeskustelujen yksi sota-aihe. Keskusteluihin vaikuttaa esimerkiksi se, miten Venäjän Karjalassa tätä sodan traumaattista kertomusta on välitetty nykyisille sukupolville julkaisujen ja leirien uhreille pystytettyjen muistomerkkien avulla. Yksi aktiivinen toimija Venäjän Karjalasssa on ollut Fasististen keskitysleirien entisten alaikäisten vankien liitto. Suomella on kaksijakoinen asema suhteessa tähän toimintaan, koska kertomukset rakentavat osittain kuvaa fasistisesta Suomesta. Yhtäältä suomalaisten tutkijoiden keräämä tieto ja suomalaiset arkistot ovat olleet tärkeitä tiedonlähteitä sodasta ja leireistä, mutta toisaalta Suomi on kieltäytynyt korvausten maksamisesta leirien uhreille, koska kertomusten tuottamaa kuvaa Suomesta ei pidetä täällä oikeana.

Sigrid Kaasik-Krogerus pohti Euroopan unionin lisääntynyttä kiinnostusta yhteisen kulttuuriperinnön tuottamiseen esityksessään "Eurooppalainen kulttuuriperintötunnus EUkansalaisten silmin". Eurooppalaisen kulttuuriperintötunnuksen (European Heritage Label) tarkoitus on muun muassa vahvistaa Euroopan sisäistä yhtenäisyyttä suurten ongelmien edessä. Tunnuksen avoimen poliittinen tarkoitus on tuottaa eurooppalaista narratiivia, korostaa kohteiden merkitystä ja kansalaisten tunnetta Eurooppaan kuulumisesta. 
Euroopan komission rahoittama mielipidetutkimus, Eurobarometri, kartoittaa vuosittain unionin kansalaisten sosiaalisia ja poliittisia mielipiteitä. Barometri on nostanut esiin unionin kansalaisten kasvaneen eurooppalaisen kulttuuriperinnön arvostuksen. Samalla keskusteluttavat kysymykset siitä, mitä tämä kulttuuriperintö on. Eurooppalaisen kulttuuriperintötunnuksen saaneiden kohteiden teemoihin ovat kuuluneet muun muassa merkittävät yksilöt, Euroopan unionin symbolit, sodat ja rauhanprosessit, holokausti, kommunistisen järjestelmän vastustus ja demokraattisen järjestelmän ja ihmisoikeuksien kehitys.

Kaasik-Krogeruksen esitys perustui kriittiseen kulttuuriperintötutkimukseen. Siinä tarkastellaan niitä merkityksiä luovia sosiaalisia, poliittisia, diskursiivisia ja performatiivisia prosesseja, joilla menneisyydelle annetaan merkityksiä nykyhetkestä käsin ja pyritään muokkaamaan tietynlaista tulevaisuutta. Muun muassa perintötunnuksen saaneiden kohteiden vierailijoiden haastatteluista nousi esiin eurooppalaisuuden tulkitsemisen monimuotoisuus ja haasteellisuus. Se on yhtä aikaa sekä kuulumisen tunne johonkin että erottautumista jostakin, mikä osoittaa, että määrittely ei ole yksiselitteistä. Miten eurooppalainen rajataan? Missä ovat Euroopan rajat? Onko myös kolonialismi yhteistä eurooppalaista kulttuuriperintöä? Mitkä perintökohteet hyväksytään eurooppalaisina ja mitkä hylätään eurooppalaisuuteen kuulumattomina? Määrittelyihin liittyvät keskeisesti kysymykset siitä, ketkä pystyvät samaistumaan, kenen halutaan kuuluvan ja kenen kanssa halutaan käydä dialogia.

Keskustelu jatkui Kaarina Aitamurron esityksellä "Vähemmistöuskontojen hallinta ja neuvottelut menneisyydestä: Mitä on Venäjän 'perinteinen islam'?". Esitys valotti nykyistä ymmärrystä "perinteisestä islamista" Venäjällä. Aitamurto kertoi, kuinka termiin törmää usein julkisessa keskustelussa, vaikka sitä on kritisoitu useasta suunnasta. Sillä viitataan sallittuun ja ihanteelliseen islamin harjoitukseen. Käsite on sidottu valtakamppailuihin, mutta samalla sitä käytetään arkikielessä kyseenalaistamattomasti.

Aitamurto yhdisti islamia käsittelevän diskursiivisen prosessin Venäjän kansallisen identiteetin rakentamiseen, jossa identiteetin yhteneväisyyden vahvistamisella taataan myös vähemmistöjen lojaalius valtiota kohtaan. Tässä diskurssissa uskontoa käsitellään dogmaattisena ja identiteettipoliittisena, ei yksityisenä asiana. Laajemmin katsottuna perinteisen islamin tuottaminen onkin osa Venäjän uskonnollista hierarkiaa tuottavaa politiikkaa ja 2000-luvun yleistä nationalistista käännettä sekä kasvavaa uskontojen kontrollia ja hallintaa. Siinä yhä useammat muslimit ja vähemmistöuskonnot joutuvat neuvottelemaan Venäjällä asemaansa suhteessa ortodoksiseen kirkkoon. "Perinteinen islam" on yksinkertaistaen luonnehdittu lojaalisuudeksi Venäjän valtiolle ja valmiudelle taistella venäläisten rinnalla jopa muita islaminuskoisia vastaan. Tässä merkityksessä islam ei saa olla poliittista vaan sen on oltava maltillista sekä kansallista uskontoa, jossa on tilaa myös paikallisille tulkinnoille.

Nämä määrittelyt sisältävät useita ristiriitaisuuksia. Esimerkiksi kansallisuuden vaatimus on monella tavalla ongelmallinen. Pitäisikö esimerkiksi imaamien koulutus ulkomailla kieltää? Lisäksi Venäjällä on erittäin paljon paikallista ja alueellista vaihtelua uskontokunnan sisällä. Suuri osa maailman muslimeista kuitenkin katsoo, ettei paikallinen kuulu islamiin. Noudatetaanko tällöin teologista vai kansallista perinnettä? Miten määritellään "hyvä" ja "paha" islam?

Seminaarin puheenvuorot nostivat esiin varsin erilaisia mielikuvien ja todellisuuksien tuottamisprosesseja. Niissä tiivistyi kuitenkin se, kuinka menneisyydestä neuvotellaan nykyhetkestä käsin. Tulevaisuutta ja yhteisöllisyyttä rakennetaan nykyhetken menneisyyttä koskevien notkeiden poliittisten esitysten varaan niin kansallisesta kuin rajanylittävästä historiallisesta muistista ja kulttuurista, ja niin Venäjällä kuin Euroopassa.

Seminaarin päättänyt paneelikeskustelu pohti Venäjän ja Itä-Euroopan tutkimusta Suomessa sekä muisteli seuran ja Idäntutkimus-lehden toimintaa eri aikoina. Paneeliin osallistuivat VIETSin edelliset puheenjohtajat Kimmo Kääriäinen ja Katalin Miklóssy sekä Idäntutkimuksen edellinen ja nykyinen päätoimittaja Markku Kangaspuro ja Katja Lehtisaari seuran nykyisen puheenjohtajan Joni Virkkusen johdolla.

Alussa muisteltiin Venäjän ja Itä-Euroopan tutkimuksen kehitystä Suomessa Neuvostoliiton romahduksen myötä. Suomessa suhtauduttiin alaan silloin eri lailla kuin muualla. Monissa maissa tutkimuksen tarpeen tulkittiin vähenevän, kun vihollinen eli Neuvostoliitto romahti. Suomessa kiinnostus entistä Neuvostoliittoa kohtaan sekä sen tutkimusta edistävät instituutiot ja rahoitus kehittyivät tuolloin kuitenkin jopa parempaan suuntaan kuin uskallettiin toivoa. Tällöin lanseerattiin muun muassa Suomen Akatemian Venäjä-ohjelmat ja Aleksanteri-instituutti perustettiin. Se kantoi. 
Myös VIETSin toiminta kehittyi. Se järjesti tapahtumia ympäri Suomea, joissa tutustuttiin tutkijoihin ja tutkimukseen eri yliopistoissa. Paneelissa todettiin, että VIETSin rooli on ollut merkittävä tutkimuksen kehittäjänä. Erotuksena kapeasti yhden tieteenalan seuroihin, se keskittyy aluetutkimukseen vahvuutenaan monitieteisyys. Toisaalta VIETSissä on kaivattu näkyvämpää omaehtoista keskustelua siitä, mitä on aluetutkimus. Mihin se on menossa? Myös mielenkiintoa Itä-Euroopan aluetta kohtaan on joutunut perustelemaan vuosien varrella eikä puhetapa välttämättä ole ollut aivan ajankohtaisesti kiinni aluetta koskevissa toimintaympäristön muutoksissa. Keskustelu myös omalla kielellä näistä asioista on tärkeää ajattelun kehittämiseksi.

Idäntutkimus-lehden uudistuminen ajoittui 2000-luvun alkuun, ja lehden levikki nousikin noin viiteensataan. Tampereen ICCEES-konferenssista (International Council for Central and East European Studies) vuonna 2000 jäänyttä pottia voitiin käyttää lehden kehittämiseen. Linjauksiin kuului, että lehden toimitus pidettiin erillisenä VIETSin hallituksesta. Tavoitteeksi asetettiin korkeatasoinen suomenkielinen tieteellinen julkaisu, joka on muidenkin kuin akateemisten luettavissa. Mukaan tuotiin muun muassa projektikohtaisia teemanumeroita. Nykyään myös maantieteellinen alue on laajentunut ja aiemman Venäjä-fokuksen rinnalle on tullut Itä-Eurooppaa ja Keski-Aasiaa käsitteleviä kirjoituksia. Yksi käänne lehden sisällössä tapahtui myös 2000-luvun alussa, jolloin taloutta käsitteleviä artikkeleita ei juurikaan tarjottu, vaikka Venäjän talous nousi. Taloustieteilijöiden kiinnostus hiipui.

Myös Ukrainan oranssi vallankumous ja poliittisen tilanteen kiristyminen heijastuivat lehteen. Oli tahoja, jotka vaativat, että lehden on otettava poliittista kantaa tilanteeseen. Se, että lehti pyrki pysymään neutraalina, tulkittiin näissä vaatimuksissa merkiksi päinvastaisesta eli puo- lueellisuudesta. Joidenkin juttujen julkaisua oli mietittävä tarkastikin. Vuosien varrella on korostunut se, että tieteellisen julkaisun on syytä olla rohkeasti tieteellinen eli välittää tutkittua tietoa ja siihen perustuvaa keskustelua ajan trendeistä ja muista paineista huolimatta, vaikka tiede ei voi myöskään vain pysyä omassa kuplassaan.

Nykyisin intohimot lehden saamassa palautteessa ovat vähentyneet, mutta yksittäistä palautetta on, ja keskustelua käydään kirjoittajien kanssa esimerkiksi tyylikysymyksistä. Suomen tutkijakunnasta kaikki eivät kirjoita suomeksi ja lehteä onkin välillä kehotettu julkaisemaan englanniksi. Vaikka tätä asiaa on hyvä pohtia aika-ajoin uudelleen, on toistaiseksi arvioitu, että englanninkielisiä julkaisuja on muutenkin tarjolla. Idäntutkimuksen rooli voidaan myös nähdä erityisen tärkeäksi nuorten tutkijoiden julkaisutoiminnan ja uran edistämisessä. Kannustaminen on tärkeää ja palaute omalla äidinkielellä on tärkeää aloitteleville tutkijoille. Mahdollisuus julkaista äidinkielellä voi myös madaltaa kynnystä tutkimuksen aloittamiseen.

Tulevaisuuteen katsottaessa kiinnitettiin huomiota digitalisaatioon, vaikka se ei vielä näy kovin paljon lehden artikkeleiden menetelmissä. Haasteeksi tieteen ja yhteiskunnan välisessä keskustelussa nähtiin jälleen esiin noussut maailman polarisoituminen. VIETSin ja Idäntutkimuksen monitieteisyys voi luoda kuvaa eri näkövinkkeleistä, minkä pitäisi olla tässä tilanteessa jälleen etu.

Näkyvyyden ja profiilin nostamiseen tarvitaan kuitenkin jatkuvasti toimenpiteitä ja luovaa ajattelua. Muun muassa VIETSin näkyvyys ja eri muotoinen yhteistyö alan tapahtumissa, niiden linkittäminen kirjoitusmahdollisuutena Idäntutkimukseen ja vertailunäkökulmien tuomat avaukset ymmärryksen piristäjinä alasta nostettiin esimerkkeinä esiin.

Olga Hannonen \& Minna Piipponen 